Marta SZULC

DOI : $10.14746 / \mathrm{pp} .2020 .25 .1 .11$

Uniwersytet Szczeciński

ORCID ID: 0000-0002-9928-305X

\title{
Polityka młodzieżowa w województwie zachodniopomorskim - wymiar lokalny i regionalny
}

\begin{abstract}
Streszczenie: W artykule podjęto tematykę polityki młodzieżowej w województwie zachodniopomorskim. Autorka w szczególności skupiła się na aspekcie lokalnym i regionalnym tejże polityki.

Jego celem jest diagnoza sytuacji polityki młodzieżowej w województwie zachodniopomorskim na poziomie regionalnym i lokalnym. Autorka postawiła następujące pytania badawcze: czy system funkcjonowania polityki młodzieżowej działa prawidłowo, jaki jest zakres tematyczny działalności rad młodzieży, czy młodzież angażująca się w politykę młodzieżową zna mechanizmy jej funkcjonowania w województwie zachodniopomorskim, czy Sekretariat ds. Młodzieży Województwa Zachodniopomorskiego oraz Rada Młodzieży Województwa Zachodniopomorskiego spełniają swoją funkcję dotyczącą prowadzenia polityki młodzieżowej w województwie zachodniopomorskim. Aby znaleźć odpowiedzi na powyższe pytania badawcze użyto: metody analizy danych zastanych, badania ankietowego oraz techniki wywiadów.

Przeprowadzone analizy wykazały rozpoznawalność i widoczność działań SdsM WZ i RMWZ w regionie. Pokazały, że RMWZ ma coraz wyraźniejszy wpływ na politykę młodzieżową oraz województwo zachodniopomorskie. Za pomocą analiz danych zaobserwowano prawidłową dynamikę powstawania rad młodzieży w województwie. Zdiagnozowano również pewne problemy polityki młodzieżowej tj. brak budżetu, brak współpracy z dorosłymi oraz niskie zaangażowanie młodzieży. Te elementy wymagają, w opinii autorki, dalszej pracy podmiotów zaangażowanych w politykę młodzieżową.
\end{abstract}

Słowa kluczowe: polityka młodzieżowa, polityka regionalna, polityka lokalna, partycypacja społeczna

\section{Wprowadzenie}

Dolityka młodzieżowa jest dość młodą dziedziną badań w Polsce. Kluczowe znaczenie dla badań nad polityką młodzieżową miało wstąpienie Polski do UE, dzięki czemu można korzystać z unijnego dorobku w tym zakresie.

Celem niniejszego artykułu jest diagnoza sytuacji polityki młodzieżowej w województwie zachodniopomorskim na poziomie regionalnym i lokalnym. Autorka badania założyła, że polityka młodzieżowa na poziomie lokalnym i regionalnym rozwijała się, w szczególności po 2005 r., tj. po powstaniu Sekretariatu ds. Młodzieży Województwa Zachodniopomorskiego (SdsM WZ) oraz Rady Młodzieży Województwa Zachodniopomorskiego (RMWZ). Podczas analizy danych zastanych oraz badania ankietowego autorka spróbuje odpowiedzieć na pytania: czy w województwie zachodniopomorskim istnieje system polityki młodzieżowej, jaki jest zakres tematyczny działalności rad młodzieży, czy młodzież angażująca się w politykę młodzieżową zna mechanizmy jej funkcjonowania w województwie zachodniopomorskim, czy Sekretariat ds. Młodzieży Województwa Zachodniopomorskiego oraz Rada Młodzieży spełniają swoją funkcję dotyczącą prowadzenia polityki młodzieżowej w województwie zachodniopomorskim. 
Badanie, którego wyniki zostaną przedstawione w poniższym artykule ma charakter unikatowy. Do tej pory, mimo dwóch publikacji, regionalnej oraz jednej ogólnopolskiej omówionych niżej, nie zostało przeprowadzone podobne badanie. Cezura czasowa artykułu obejmuje okres od wstąpienia Polski do Unii Europejskiej do czasu zakończenia badania, które miało miejsce w maju 2019 roku.

$\mathrm{W}$ artykule wykorzystano analizę danych zastanych oraz przeprowadzono badanie ankietowe. Z zastosowaniem metody badawczej „desk reaserch” przeanalizowano sprawozdania Sekretariatu ds. Młodzieży Województwa Zachodniopomorskiego, raporty wykonane na jego zlecenie, dokumenty oraz publikacje z zakresu kreowania polityki młodzieżowej. Badanie ilościowe, wykonane za pomocą metody ankiety on-line (wsparte kontaktem z opiekunami lokalnych rad młodzieży) miało być uzupełnieniem analizy danych zastanych i przedstawieniem polityki młodzieżowej, z perspektywy jej uczestników- członków rad młodzieży województwa zachodniopomorskiego. Dla uzupełnienia wyników badań ilościowych przeprowadzono także badanie jakościowe - wywiady (rozmowy) z osobami związanymi z młodzieżową polityką lokalną w województwie zachodniopomorskim.

Na samym początku rozważań warto pochylić się nad samym pojęciem polityki młodzieżowej. Opracowania wskazują, że temat polityki młodzieżowej w Polsce zaczął się rozwijać w 2003 roku, co było związane z pracami przygotowawczymi do wstąpienia Polski do UE. Według Strategii Państwa dla Młodzieży na lata 2003-2012 „polityka młodzieżowa uznawana jest w krajach europejskich za międzyresortową, zintegrowaną politykę wobec młodych ludzi, wywodzącą się z ich potrzeb. Celem polityki młodzieżowej jest stworzenie odpowiednich warunków bytowych dla młodych ludzi, umożliwienie im uczestnictwa w życiu publicznym, udziału w życiu społecznym, kulturalnym i politycznym na równi z innymi grupami społecznymi”. Według innej, zbliżonej definicji „Polityka młodzieżowa, to celowe, spójne i zaplanowane działanie wobec młodzieży przy użyciu dostępnych dla danego poziomu władzy narzędzi. Jest to przyjęty i realizowany przez władzę publiczną i organizacje pozarządowe zespół długofalowych działań na rzecz zaspokajania potrzeb i rozwiązywania problemów społecznych młodzieży" (Skocz, Postawa, Prokopowicz, 2009, s. 7). Biorąc pod uwagę wymiar lokalny i regionalny polityki młodzieżowej, warto przybliżyć jeszcze fragment znowelizowanej Europejskiej Karty Uczestnictwa Młodych Ludzi w Życiu Lokalnym i Regionalnym Kongresu Europejskich Władz Lokalnych i Regionalnych: „Aktywne uczestnictwo młodych w decyzjach i przedsięwzięciach na szczeblu lokalnym i regionalnym jest niezbędne, jeżeli chcemy budować społeczeństwa bardziej demokratyczne, bardziej solidarne i bardziej dostatnie. Uczestnictwo w życiu demokratycznym danej społeczności nie polega tylko na głosowaniu, lub na kandydowaniu w wyborach, mimo że są to elementy bardzo ważne. Uczestniczyć i być obywatelem aktywnym, to znaczy mieć prawo, środki, miejsce, możliwość i jeśli to konieczne, wsparcie wymagane w uczestnictwie w decyzjach, wpływać na nie i angażować się w akcje i działalność, w sposób przyczyniający się do ustanowienia lepszego społeczeństwa". W artykule skupiono się na wymiarze lokalnym i regionalnym kreowania polityki młodzieżowej, czyli na mechanizmach sprzyjających czy też utrudniających młodzieży aktywność w życiu publicznym. $Z$ uwagi na regionalny charakter badań nie badano zapisów dotyczących młodzieży w politykach publicznych (EKUMLiR). 
Elementem definicji młodzieży jest jej przedział wiekowy. Wiele źródeł podaje różne definicje młodzieży, w oparciu o kryterium wieku. W jednej z klasycznych definicji młodzież ujmowana jest jako grupa społeczna pomiędzy 15 a 25-29 rokiem życia (Chodubski, 2014, s. 12), według szerszych definicji młodzież to grupa wiekowa pomiędzy 13 a 30 rokiem życia (Sińczuch, 2009, s. 147). W badaniu funkcjonowania rad młodzieży respondenci byli pomiędzy 15 a 20 rokiem życia.

Artykuł został podzielony na kilka części. W pierwszej przedstawiono historię tworzenia się struktur odpowiedzialnych za kreowanie polityki młodzieżowej w województwie zachodniopomorskim na poziomie regionalnym i lokalnym. Druga część przedstawia wyniki badania przeprowadzonego w maju 2019 roku wśród zachodniopomorskich rad młodzieży. Badanie ankietowe uzupełniono o rozmowy z osobami związanymi z lokalną polityką młodzieżową. W ostatniej części przedstawiono wnioski zarówno z analizy danych zastanych, jak i z przeprowadzonego badania.

\section{Polityka młodzieżowa w województwie zachodniopomorskim}

W przypadku województwa zachodniopomorskiego, rozwój polityki młodzieżowej także zbiega się z wstąpieniem Polski do UE. Władze samorządowe województwa zachodniopomorskiego zajęły się tematyką polityki młodzieżowej jako jedne z pierwszych w Polsce. Istotnym krokiem było powołanie Sekretariatu ds. Młodzieży Województwa Zachodniopomorskiego (uchwałą Sejmiku Województwa Zachodniopomorskiego z 20 grudnia 2004 r.). Jednostka ta zaczęła funkcjonować 2 maja 2005 roku. Wśród zadań tej samodzielnej jednostki budżetowej znalazło się: „wspieranie idei samorządności wśród młodzieży, umożliwianie podejmowania różnych działań przez młodych ludzi w sferze publicznej i społecznej, włączanie młodych w procesy podejmowania decyzji na szczeblu samorządowym, zapewnienie łączności pomiędzy strukturami samorządowymi i młodzieżą oraz międzyregionalny rozwój współpracy młodzieży" (SdsM WZ).

Powstanie takiej jednostki było nie tylko ważne z punktu widzenia współpracy transgranicznej. Według badania z 1999 r. tylko 24\% zachodniopomorskiej młodzieży stwierdziło, iż aktywnie uczestniczy w działalności jakiejś organizacji lub zorganizowanej grupy, a 70\% młodych ludzi nie należało do żadnej organizacji (Czubara, 2008, s. 22).

Jednym z pierwszych zadań SdsM WZ było opracowanie koncepcji powoływania i funkcjonowania Rady Młodzieży Województwa Zachodniopomorskiego (RMWZ). Impulsem do tego działania był transgraniczny projekt „Perspektywy Młodzieży w Regionach po wejściu Polski do Unii Europejskiej”. Utworzenie regionalnego przedstawicielstwa młodzieży było jedną z konkluzji wspólnych obrad młodzieży. Wobec braku regulacji centralnych, SdsM WZ wypracował nową koncepcję w oparciu o konsultacje ze środowiskiem młodzieżowym oraz dyskusje w Komisji Edukacji, Kultury i Sportu Sejmiku. Reprezentacja młodzieży w RMWZ jest dość szeroka, znacznie szersza niż w dotychczas funkcjonujących lokalnie radach młodzieży. Oprócz uczniów szkół ponadgimnazjalnych zrzeszonych w radach młodzieży miast i gmin, RMWZ zrzesza także: młodzież działającą w samorząach studenckich, radach młodzieży oraz organizacjach pozarządowych z terenu całego województwa (Sprawozdanie z działalności, 2017). 
Pierwsze posiedzenie RMWZ odbyło się 6 kwietnia 2006 r. Według Sprawozdania z działalności Sekretariatu ds. Młodzieży z 2005 r. było to pierwsze takie przedstawicielstwo młodzieży w Polsce ${ }^{1}$. RMWZ za najważniejsze kierunki działania przyjęła wówczas: promowanie idei samorządności, zapewnianie udziału młodzieży w budowie społeczeństwa obywatelskiego, rozwijanie postaw zaangażowania w sprawy regionu, podejmowanie działań wynikających z uchwał Sejmiku Województwa (SdsM WZ, 2007). Pierwsze lata funkcjonowania RMWZ nie były zbytnio aktywne. W 2008 roku RMWZ przygotowała Europejski Tydzień Młodzieży, a w roku 2009 r. współtworzyła projekt „Ku Demokracji”, którego efektem była jedna z dwóch stworzonych do tej pory analiz polityki młodzieżowej w województwie zachodniopomorskim² ${ }^{2}$

$\mathrm{Na}$ poziomie lokalnym obecnie funkcjonuje $20 \mathrm{rad}$ młodzieży. $16 \mathrm{z}$ nich powstało po roku 2005, dzięki wsparciu SdsM. Jak pokazuje tabela 1 do roku 2005 MRM oprócz dwóch największych miast regionu (Szczecin, Koszalin) działały jeszcze tylko w Białogardzie i Pyrzycach. Od 2001 r. działała jeszcze Rada Młodzieży w Złocieńcu, która obecnie nie funkcjonuje. Źródła SdsM WZ podają (SdsM WZ, 2007), iż w 2007 r. w Polsce funkcjonowało 90 rad młodzieży. Według danych pochodzących z badania zawartego w publikacji „O młodzieżowych radach” Rady Dzieci i Młodzieży Rzeczypospolitej Polskiej przy Ministrze Edukacji Narodowej w 2018 roku w 2478 gminach funkcjonowało 408 Młodzieżowych Rad Gmin i ich odpowiedników. Powyższe dane wskazują, że rozwój polityki młodzieżowej jest widoczny także w wymiarze liczbowym. Co prawda liczba rad młodzieży nie jest wciąż imponująca, ale wzrost jest z pewnością informacją pozytywną (Raport..., 2018, s. 14).

Tabela 1

Młodzieżowe Rady Miast/ Gmin w województwie zachodniopomorskim

\begin{tabular}{|c|c|c|}
\hline l.p. & Nazwa rady mlodzieży & Data powstania \\
\hline 1 & 2 & 3 \\
\hline 1 & Młodzieżowa Rada Miasta Szczecin & $20.03 .1995 \mathrm{r}$. \\
\hline 2 & Młodzieżowa Rada Miasta Białogard & $1997 \mathrm{r}$. \\
\hline 3 & Młodzieżowa Rada Miasta Koszalin & $\begin{array}{c}\text { 09.06.1995-2009 r. (IX kadencja), } \\
\text { 2015, } 2018 \text { (XI kadencja) }\end{array}$ \\
\hline 4 & Młodzieżowa Rada Miasta Pyrzyce & 2001 \\
\hline 5 & Młodzieżowa Rada Miasta w Kołobrzegu & 2007-2013 2015-do dziś \\
\hline
\end{tabular}

${ }^{1}$ Taką samą informację podaje wiele źródeł. Pewna rozbieżność występuje w najnowszej publikacji: Polityka młodzieżowa w Polsce, Joanna Dąbrowska-Resiak, Mateusz Jeżowski, FRSE 2019. M. Konieczny w artykule Polityka młodzieżowa w Polsce - podstawowe informacje podaje, że pierwszą radą był Parlament Dzieci i Młodzieży Województwa Lubelskiego, powołany w 1996 roku. To co odróżnia Parlament Lubelski to: ograniczony wiek - 13-21, dzieci i młodzież jedynie ze szkół. Parlament działa pod kuratorium, a RMWZ pod Marszałkiem Województwa. Z uwagi na te różnice możemy wywnioskować, iż stwierdzenie o pierwszym takim przedstawicielstwie młodzieży na wzór europejski w Polsce jest prawdziwe.

2 Pierwsza analiza dotyczy aktywności młodzieży: Aktywność, tożsamość, plany $i$ oczekiwania młodzieży województwa zachodniopomorskiego, T. Czubara, Szczecin 2008. Druga to fragment publikacji Młodzi o polityce młodzieżowej w regionie Morza Battyckiego. Dokumentacja projektu „,Krok ku demokracji”. Pierwsza z pozycji jest analizą głównie socjologiczną, interpretującą wcześniejsze dane i badania (np. z 2009). W drugiej opisano stan polityki młodzieżowej oraz przeprowadzono krótką ankietę wśród młodzieży dotyczącą problemów młodzieży województwa zachodniopomorskiego. 


\begin{tabular}{|r|l|c||}
\hline \multicolumn{1}{|c|}{1} & \multicolumn{1}{|c||}{2} & 3 \\
\hline 6 & Młodzieżowa Rada Miasta Świdwin & 2008 \\
\hline 7 & Młodzieżowa Rada Gminy Barlinek & 2012 \\
\hline 8 & Młodzieżowa Rada Regionu Polickiego & 2009 \\
\hline 9 & Młodzieżowa Rada Miasta Choszczno & 2011 \\
\hline 10 & Młodzieżowa Rada Miejska Gryfino & 2016 \\
\hline 11 & Młodzieżowa Rada Miejska w Łobzie & $2015-2017$ \\
\hline 12 & Młodzieżowa Rada Miasta Myślibórz & 2007 \\
\hline 13 & Młodzieżowa Rada Gminy Mielno & 2015 \\
\hline 14 & Młodzieżowa Rada Miejska w Karlinie & 2013 \\
\hline 15 & Młodzieżowa Rada Miasta Kamień Pomorski & 2010 \\
\hline 16 & Młodzieżowa Rada Miasta Resko & 24.06 .2016 \\
\hline 17 & Młodzieżowy Zespół Doradczy Prezydenta Miasta Stargard & 2013 \\
\hline 18 & Młodzieżowa Rada Miasta w Dębnie & 2012 \\
\hline 19 & Społeczna Rada Młodzieży w Czaplinku & 2008 \\
\hline 20 & Młodzieżowa Rada Miasta Darłowo & 2012 \\
\hline
\end{tabular}

Źródło: Opracowanie własne na podstawie strony młodzież.wzp.pl i oficjalnych serwisów miast i gmin.

Oprócz rad młodzieży wymienionych w tabeli funkcjonowały jeszcze 3 MRM, które obecnie nie funkcjonują: Młodzieżowa Rada Miasta Gryfice (2014-2015), Młodzieżowa Rada Miasta i Gminy Złocieniec (2003-2016), Młodzieżowa Rada Miasta Świnoujście (2010-2014). W przeprowadzonym w kwietniu 2019 roku badaniu autorka artykułu zapytała osoby wcześniej zaangażowane w prace rad młodzieży o obecną sytuację oraz o powody zakończenia działalności przez dwie z tych rad. Na temat sytuacji w Złocieńcu wypowiedziała się wieloletnia radna Rady Miejskiej w Złocieńcu - Elżbieta Frankowska: „Bywało tak, że na spotkania radnych, które sobie wyznaczyli przychodziło - 1-3 radnych, no w porywach 5... [...] W czerwcu 2016 roku ostatnia kadencja zakończyła działalność. Myślę, że trzeba popracować nad zmianą powoływania rady. Dać dojść do głosu tym, którzy chcą naprawdę działać... Do wyborów często startują $\mathrm{Ci}$, których celem jest wygrać, niekoniecznie potem działać [...] Z rozrzewnieniem wspominam czasy, gdy się ludziom chciało chcieć”. Sytuację Rady Młodzieży w Świnoujściu skomentował Jan Borowski, radny Rady Miasta Świnoujście. „Rada zakończyła swoją działalność 5 lat temu. Miała zostać odtworzona na jesieni zeszłego roku, teraz jest mowa o wrześniu. Opór jest po stronie prezydenta". Wskazane osoby w przytoczonych wypowiedziach zwracają uwagę na zupełnie inne aspekty działalności i funkcjonowania rad młodzieży.

Na poziomie regionalnym możemy zaobserwować profesjonalizację oraz przyjęcie modeli europejskich (europeizację top down) w działaniach Rady Młodzieży Województwa Zachodniopomorskiego. Z organizacji, która stawiała swoje pierwsze kroki podpatrując swoje europejskie odpowiedniki dziś jest to gremium, które z okazji 15-lecia członkowstwa Polski w Unii Europejskiej ustaliło i wygłosiło swoje rekomendacje dla regionu. Rekomendacje zawierały analizę 15 obszarów ważnych dla młodzieży: edukacji, aktywności społecznej, świadomości obywatelskiej, Wojewódzkiej Karty Młodych, rynku pracy, życia młodych, zdrowia, edukacji seksualnej, osób zagrożonych wykluczeniem, spójności komunikacyjnej, Zachodniopomorskiej Karty Aglomeracyjnej, wsparcia językowego, mobilności edukacyjnej, potencjału turystycznego, współpracy regionalnej i międzyregionalnej. Pierwsze przedstawienie rekomendacji odbyło się 10 maja 
2019 r. podczas uroczystej sesji Rady Młodzieży Województwa Zachodniopomorskiego (informacje z Sekretariatu ds. Młodzieży). W dniu 24.06.2019 r. radni RMWZ wraz z pracownicą SdsM WZ przedstawili swoje rekomendacje podczas posiedzenia Komisji Oświaty, Kultury i Sportu Sejmiku Województwa Zachodniopomorskiego (rozmowa z Kornelem Grabowskim - przewodniczącym RMWZ).

\section{Badanie radnych zachodniopomorskich Rad Młodzieży}

Wypowiedzi osób wcześniej zaangażowanych w lokalną politykę młodzieżową dotyczące lokalnych rad młodzieży skłoniły autorkę artykułu do przeprowadzenia badania aktywności radnych młodzieżowych rad województwa zachodniopomorskiego.

Badanie przeprowadzono w maju $2019 \mathrm{r}$. w formie elektronicznej za pomocą formularza ankiety. O udział w badaniu poproszono członków 20 lokalnych zachodniopomorskich rad młodzieży oraz członków Rady Młodzieży Województwa Zachodniopomorskiego. W ankiecie zawarto zarówno pytania otwarte, jak i zamknięte.

W wyniku badania otrzymano 21 odpowiedzi z 7 młodzieżowych rad miasta/miasta i gminy (MRM) i z Rady Młodzieży Województwa Zachodniopomorskiego (RMWZ). Mimo, że zostały przeprowadzone rozmowy telefoniczne z wszystkimi opiekunami rad lokalnych, nie ze wszystkich rad młodzieży uzyskano informacje zwrotne. Dlatego też przyjęto założenie, że przebadano aktywnych członków MRM Województwa Zachodniopomorskiego oraz RMWZ, a w analizie wyników badania autorka postanowiła unikać generalizacji. Warto jednak zaznaczyć, że w ogólnopolskim badaniu Rady Dzieci i Młodzieży RP działającej przy Ministrze Edukacji Narodowej, którego wyniki przedstawiono w 2018 r., na 408 funkcjonujących rad młodzieży w Polsce otrzymano wyniki od ok. 120 radnych, w zależności od pytania. Co oznacza, że w przedstawionym poniżej badaniu występuje zbliżony, a nawet wyższy udział odpowiedzi zwrotnych z rad młodzieży niż w badaniu ogólnopolskim zrealizowanym we współpracy z wieloma podmiotami.

Najwięcej odpowiedzi pochodzi z MRM Świdwin (6), następny w kolejności jest Stargard (5), RMWZ (4) Choszczno (2) oraz Szczecin (1), Myślibórz (1), Kołobrzeg (1). Jedna $\mathrm{z}$ ankietowanych osób nie udzieliła odpowiedzi na to pytanie. Większość z ankietowanych jest w radzie młodzieży powyżej roku (52,4\%), 9,5\% jest członkiem rady młodzieży powyżej 2 lat. Ankietowani są w wieku od 15 do 20 lat. Najwięcej (15) respondentów jest w przedziale wiekowym 17-19 lat.

W pierwszym pytaniu młodzi ludzie zostali zapytani o motywację do działania w MRM. Ankietowani mogli wskazać co najwyżej 3 z poniższych odpowiedzi:

- chęć zrobienia czegoś dla młodych ludzi;

- chęć zrobienia czegoś dla najbliższego otoczenia;

- możliwość sprawowania władzy;

- rozwój osobisty;

- zdobywanie doświadczenia zawodowego;

- realizacja własnych ambicji.

Najczęściej padającymi odpowiedziami były: rozwój osobisty (16), zdobywanie doświadczenia zawodowego (15), chęć zrobienia czegoś dla młodych ludzi (13) i chęć 
zrobienia czegoś dla najbliższego otoczenia (12). Najrzadziej padały odpowiedzi: możliwość sprawowania władzy (3) i realizacja własnych ambicji (3).

Autorkę badania zainteresowało jakie były dwie pozostałe odpowiedzi osób, które wybrały jako motywujący fakt, iż działając w MRM ma się możliwość sprawowania władzy. Analiza odpowiedzi wskazała, że osoby te wskazały również odpowiedź „rozwój osobisty”. Dwie z tych osób wybrały także ,zdobywanie doświadczenia zawodowego”, a jedna „realizację własnych ambicji”. Co ciekawe, żadna z ankietowanych osób nie wskazała łącznie „,chęci zrobienia czegoś...” i „możliwości sprawowania władzy”.

Ankietowani zostali także poproszeni o wskazanie działań rad młodzieży, w które byli zaangażowani w obecnej kadencji. Dzięki tym odpowiedziom możemy stworzyć zarys tematyczny działalności rad młodzieży w województwie zachodniopomorskim. Autorka badania pogrupowała odpowiedzi dzieląc je na: aktywność społeczną, aktywność społeczno-polityczną, aktywność polityczną. Jedna z odpowiedzi („Dużo tego”) nie została przypisana do żadnej z kategorii. Zestawienie odpowiedzi radnych (w oryginalnej pisowni) zawiera tabela 2 .

Tabela 2

\section{Działania Rad Młodzieży w województwie zachodniopomorskim}

\begin{tabular}{|c|c|c|}
\hline Aktywność społeczna & Aktywność spoleczno-polityczna & Aktywność polityczna \\
\hline $\begin{array}{l}\text { imprezy młodzieżowe, } \\
\text { wspomaganie innych orga- } \\
\text { nizacji ( } 2 \text { odpowiedzi) }\end{array}$ & $\begin{array}{l}\text { VI edycja przeglądu młodych muzy- } \\
\text { ków, Kongres Samorządów Uczniow- } \\
\text { skich }\end{array}$ & $\begin{array}{l}\text { I Szczeciński Kongres Młodych, } \\
\text { Młodzieżowy Budżet Obywatelski }\end{array}$ \\
\hline $\begin{array}{l}\text { Ślij Życzenia, Art Festiwal } \\
\text { Dni Pionierów Stargardu }\end{array}$ & Europejski Tydzień Młodzieży & $\begin{array}{l}\text { działania profrekwencyjne na rzecz } \\
\text { wyborów do PE, aktywizowanie } \\
\text { młodzieży w mieście poprzez pro- } \\
\text { jekty, reprezentacja rady na kongre- } \\
\text { sach i panelach, również za granicą }\end{array}$ \\
\hline $\begin{array}{l}\text { są to imprezy między inny- } \\
\text { mi zakończenie wakacji, dni } \\
\text { miasta, biegi itp. }\end{array}$ & $\begin{array}{l}\text { udział w Zielonym Wolontariacie } \\
\text { w Szczecinie dot. Agendy 2030, } \\
\text { współpraca z całą Radą Młodzieżową } \\
\text { w celu przygotowania imprezy dla } \\
\text { młodzieży pod nazwą „,Youth Friday”, } \\
\text { udział w Gali „UE Inspiruje Pomorze } \\
\text { Zachodnie” w Szczecinie }\end{array}$ & $\begin{array}{l}\text { Tramwajem do Parlamentu Euro- } \\
\text { pejskiego, Forum Młodzieży przy } \\
\text { Forum Regionalnych Parlamentów } \\
\text { Południowego Bałtyku }\end{array}$ \\
\hline impreza młodzieżowa & $\begin{array}{l}\text { wypracowywanie rekomendacji Euro- } \\
\text { pejskich, pomoc przy Marszu Równo- } \\
\text { ści }\end{array}$ & $\begin{array}{l}\text { rekomendacje na } 15 \text {-lecie wejścia } \\
\text { Polski do UE }\end{array}$ \\
\hline $\begin{array}{l}\text { gra plenerowa na terenie } \\
\text { miasta, festiwal kolorów }\end{array}$ & $\begin{array}{l}\text { działania profrekwencyjne, Europejski } \\
\text { Tydzień Młodzieży }\end{array}$ & \\
\hline \multirow[t]{4}{*}{$\begin{array}{l}\text { różne imprezy, spotkania, } \\
\text { pomoc w przygotowaniach }\end{array}$} & $\begin{array}{l}\text { sesje, rozdawanie cukierków, opieka } \\
\text { nad imprezami }\end{array}$ & \\
\hline & $\begin{array}{l}\text { Europejski Tydzień w Szczecinie, deba- } \\
\text { ta w kancelarii premiera w Warszawie }\end{array}$ & \\
\hline & $\begin{array}{l}\text { półroczny projekt Znam Stargard, Kon- } \\
\text { gres SU i inne, w których mój udział nie } \\
\text { był aż tak bardzo wyodrębniony }\end{array}$ & \\
\hline & $\begin{array}{l}\text { wszystkie!!! kongresy, konkursy, akcje } \\
\text { miejskie itp. }\end{array}$ & \\
\hline
\end{tabular}

Źródło: Badanie: Funkcjonowanie Rad Młodzieży w województwie zachodniopomorskim, M. Szulc. 
Według autorki najłatwiej było przyporządkować odpowiedzi do kategorii ,aktywność społeczna". Najtrudniej było oddzielić odpowiedzi wskazujące na ,aktywność społeczno- polityczną” od „aktywności politycznej”. Dla potrzeb badania uznano, iż Europejski Tydzień Młodzieży ma charakter społeczno-polityczny (ze względu na fakt, iż jest on organizowany z inicjatywy Komisji Europejskiej).

Warto zaznaczyć, iż 66,7\% badanych wskazuje, że jest usatysfakcjonowanych z liczby działań, w które się angażowali w czasie obecnej kadencji. Osoby nieusatysfakcjonowane $(33,3 \%-7)$ uzasadniają swoją odpowiedź w poniższy sposób:

- „Moim zdaniem, mogłam zrobić zdecydowanie więcej i w związku z tym więcej działań podejmę w przyszłej kadencji”;

- „Chciałbym zdecydowanie więcej, lecz również mam szkołę przez co brak czasu na więcej działań";

- „Jestem w stanie czynnie uczestniczyć w każdej imprezie kulturalnej z różnych dziedzin i liczę na większą liczbę organizowanych imprez, abym mogła poszerzać moją wiedzę i wzbogacać się o nowe doświadczenia";

- „Gdyby nie matura, mógłbym zrobić znacznie więcej”;

- „Ponieważ w pewnym momencie zepsuła się współpraca pomiędzy mną a kilkoma członkami rady";

- „Chciałabym podjąć więcej inicjatyw, które mogłyby zmienić jakoś lokalne otoczenie";

- „Mogło by być ich więcej”.

W badaniu zapytano także co według ankietowanych utrudnia MRM realizację wydarzeń/inicjatyw. W pytaniu wielokrotnego wyboru zaproponowano 3 odpowiedzi, a każdy z ankietowanych mógł dopisać własny czynnik utrudniający działania MRM. Najwięcej ankietowanych (19) wskazało, iż największym problemem przy organizowaniu wydarzeń/inicjatyw jest niski budżet lub jego brak, dziesięć osób wskazało na problem w postaci niskiego zaangażowania lokalnej młodzieży, dziewięcioro ankietowanych za czynnik utrudniający uznało brak współpracy z dorosłą Radą Miasta/prezydentem/wójtem/burmistrzem. Wśród „odpowiedzi własnych” ankietowanych pojawił się pseudonim pochodzący od nazwiska jednego z radnych MRM oraz „momentalny brak aktywizacji i zapału ze strony młodych ludzi”.

Badanych zapytano także co ułatwia/ułatwiałoby MRM realizację działań. W tym przypadku zaproponowano radnym 5 odpowiedzi. Ankietowani mogli wybrać kilka z nich oraz zaproponować własną. Najbardziej popularną odpowiedzią okazała się: budżet i łatwe finansowanie działań (15), następną w kolejności była: bardzo zaangażowani radni Rady Młodzieży (13). Powyżej połowa ankietowanych (11) uznała za czynnik ułatwiający realizację działań zaangażowaną młodzież. Mniejszą popularnością cieszyły się następujące propozycje: wsparcie w Radzie Miasta/u prezydenta/wójta (9) oraz łatwe/łatwiejsze procedury przy organizacji wydarzeń. Jedna z osób podała, że czynnikiem ułatwiającym realizację działań przez MRM jest radny Michał Barszczak (członek Młodzieżowego Zespołu Doradczego przy Prezydencie Stargardu).

W kolejnej części badania ankietowanym zadano pytania dotyczące Sekretariatu ds. Młodzieży Województwa Zachodniopomorskiego i Rady Młodzieży Województwa Zachodniopomorskiego. Odpowiedzi na te pytania miały wskazać czy radni orientują się w mechanizmach polityki młodzieżowej w województwie zachodniopomorskim. 
Na pytanie: „Czy znane Ci są działania Sekretariatu ds. Młodzieży Województwa Zachodniopomorskiego?" siedemnaścioro radnym udzieliło odpowiedzi twierdzącej, cztery osoby udzieliły odpowiedzi: „nie”. Kolejne z pytań dotyczyło Rady Młodzieży Województwa Zachodniopomorskiego. Na pytanie: „Czy znasz reprezentantów Rady Młodzieży Województwa Zachodniopomorskiego?" szesnaście osób odpowiedziało twierdząco, a pięć osób stwierdziło, iż nie zna reprezentantów RMWZ. Na pytanie „Czy wiesz czym zajmuje się Rada Młodzieży Województwa Zachodniopomorskiego? 85,7\% ankietowanych udzieliło twierdzącej odpowiedzi, 14,3\% respondentów nie wie czym zajmuje się RMWZ. W następnym pytaniu przewaga odpowiedzi twierdzących nie była już tak znacząca. Na pytanie: Czy brałeś/aś udział w działaniach organizowanych przez Sekretariat ds. Młodzieży Województwa Zachodniopomorskiego/Radę Młodzieży Województwa Zachodniopomorskiego? 52,4\% ankietowanych (11) udzieliło odpowiedzi twierdzącej, a 47,6\% (10 osób) udzieliło odpowiedzi negatywnej. Biorąc pod uwagę dużą liczbę wydarzeń skierowanych do młodych radnych ten ostatni wynik może nieco niepokoić. Należałoby sprawdzić, czy przypadkiem do udziału w aktywnościach nie są ciągle wybierane te same osoby.

Autorka badania postanowiła sprawdzić jakich odpowiedzi na powyższe 4 pytania udzieliły osoby, które w jednym z wcześniejszym pytań odpowiedziały, iż ich motywacją do działania w MRM jest możliwość sprawowania władzy. Autorka badania założyła bowiem, iż osoby którym zależy na możliwości sprawowania władzy powinny być na bieżąco z działaniami organizowanymi przez Sekretariat ds. Młodzieży i Radę Młodzieży Województwa Zachodniopomorskiego. W szczególności w przypadku RMWZ dlatego, iż aktywność RMWZ jest bardziej oparta o aktywność polityczną niż działalność rad lokalnych. Niestety analiza tych trzech ankiet nie potwierdziła tego założenia. Jedynie pierwsza z tych osób odpowiedziała twierdząco na wszystkie pytania dotyczące Sekretariatu ds. Młodzieży Województwa Zachodniopomorskiego i Rady Młodzieży Województwa Zachodniopomorskiego. Pozostałe dwie osoby odpowiedzi twierdzącej udzieliły jedynie w jednym przypadku. Pierwsza stwierdziła, że zna reprezentantów RMWZ, a druga, że wie czym zajmuje się RMWZ.

Autorka badania założyła także, znając wysiłki SdsM WZ, że wszyscy radni młodzieżowych rad z województwa zachodniopomorskiego znają działania SdsM WZ i RMWZ. Brak 100\% odpowiedzi ankietowanych w tym zakresie pokazuje jak wiele ta jednostka ma do zrobienia.

$\mathrm{Na}$ ankietę dla młodzieży postanowiła także odpowiedzieć opiekunka Młodzieżowej Rady Miasta Kołobrzeg. Z uwagi na określenie innej grupy badawczej wyjęto tę odpowiedź z powyższych rozważań, niemniej jednak warto przedstawić jej głos dotyczący funkcjonowania Młodzieżowej Rady Miasta w Kołobrzegu.

Jej zdanie nie różniło się zbytnio od zdania młodzieży. Opiekunce MRM w Kołobrzegu doskonale są znane działania zarówno Rady Młodzieży Województwa Zachodniopomorskiego, jak i Sekretariatu ds. Młodzieży (w tym przypadku brak znajomości tych podmiotów byłby niezwykle niepokojący). Za główne punkty, które utrudniają pracę rady młodzieży uznała: brak/niski budżet oraz małe zaangażowanie młodzieży. Opinię, o konieczności większego zaangażowania młodzieży wyraziła także w ostatnim punkcie ankiety, w którym znalazło się miejsce na własne przemyślenia ankietowanych. 


\section{Wnioski}

Polityka młodzieżowa w województwie zachodniopomorskim jest istotnym elementem polityki regionalnej i lokalnej. Na poziomie regionalnym jest widoczny także jej komponent transgraniczny, europejski.

W 2005 roku na Pomorzu Zachodnim powołano unikatową w skali Polski jednostkę budżetową odpowiedzialną za kształtowanie polityki młodzieżowej na poziomie regionalnym i lokalnym. Jednych z zadań tej jednostki, tj. Sekretariatu ds. Młodzieży Województwa Zachodniopomorskiego jest promowanie powstawanie i wspieranie działania rad młodzieży. Od czasu powstania SdsM WZ można zaobserwować wzrost liczby lokalnych rad młodzieży w województwie. Trudno jednak, mimo widocznych starań SdsM. WZ, przypisać ich powstanie wyłącznie tej jednostce budżetowej, bowiem po 2005 r. wzrosła liczba młodzieżowych rad w całej Polsce (z 90 w 2007 r. do 408 w 2018 r.). W dodatku wyniki przeprowadzonego badania wskazują, że 19\% ankietowanych członków rad młodzieży nie wie czym zajmuje się SdsM WZ. Niemniej jednak warto zauważyć, iż przeprowadzone badanie wykazało wysoką rozpoznawalność SdsM WZ jako podmiotu oraz wiele przykładów inicjatyw SdsM WZ i RMWZ. W regionie widoczne są starania SdsM WZ i ogrom pracy, jaki wykonują każdego dnia.

Analizując dane zastane można wysunąć wniosek, że powstanie takiej jednostki budżetowej było słusznym posunięciem. Raporty tej jednostki wskazują, że wykonuje ona szereg starań na rzecz rozwoju polityki młodzieżowej w województwie zachodniopomorskim, jest ona elementem wspierającym rozwój lokalnych rad młodzieży oraz prowadzi działania mające na celu ich profesjonalizację.

Pewnym unikatem na skalę krajową jest funkcjonowanie Rady Młodzieży Województwa Zachodniopomorskiego. Mimo upływu już długiego czasu od jej powstania, to wciąż takie przedstawicielstwa nie są powszechne w Polsce. Analiza danych zastanych wskazuje, że początkowo, mało aktywna RMWZ, obecnie ma coraz wyraźniejszy wpływ na regionalną i lokalną politykę młodzieżową oraz województwo zachodniopomorskie. Na wyróżnienie zasługują rekomendacje rady dla władz województwa zachodniopomorskiego na 15-lecie Polski w UE, a w szczególności ich konsultacyjny charakter. Warto podkreślić także, że działania RMWZ są widoczne również poza granicami państwa, np. dzięki jednej z aktywności profrekwencyjnych ,Tramwajem do Parlamentu Europejskiego" Rada została laureatem konkursu Europejskiego Kongresu Rad Młodzieżowych (Komisja Europejska).

W województwie zachodniopomorskim, podobnie jak w innych województwach można zaobserwować wzrost liczby młodzieżowych rad miast czy gmin. Mimo, że ich liczba od 2005 r. wzrosła ponad czterokrotnie, to wciąż jest ona mniejsza niż średnia liczba młodzieżowych rad w innych polskich województwach (obecnie średnia wynosi 25,5 rady na województwo). Warto zaznaczyć jednak, iż dynamika powstawania rad jest prawidłowa.

W badaniu, które przeprowadzono w maju 2019 roku, uzyskano pewien obraz lokalnych rad młodzieży w województwie zachodniopomorskim. Niestety, nie udało się uzyskać odpowiedzi na zadane pytania od radnych ze wszystkich młodzieżowych rad, ale okazuje się, że udział procentowy odpowiedzi jest podobny do wyniku badań ogólnopolskich. Z badania wynika, iż główną motywacją młodych ludzi do aktywności jest chęć zrobienia czegoś dla młodych ludzi i otoczenia, rozwój osobisty i możliwość 
zdobywania doświadczenia zawodowego. Mimo wielu utrudnień, m.in. braku budżetu ${ }^{3}$ młodzi ludzie są zaangażowani w szereg lokalnych wydarzeń społecznych, społeczno-politycznych i politycznych. Niestety okazało się, że nie wszyscy uczestnicy badania wiedzą czym jest Rada Młodzieży Województwa Zachodniopomorskiego i Sekretariat ds. Młodzieży Województwa Zachodniopomorskiego. W związku z powyższym, jest to pewien obszar do poprawy dla RMWZ i SdsM WZ.

Zarówno analiza danych zastanych, przeprowadzone badanie ankietowe, jak i kilka rozmów przeprowadzonych z politykami czy osobami związanymi z lokalną polityką młodzieżową, wskazują dodatkowo na dwa problemy, obecne także w polityce ogólnopolskiej, tj. brak współpracy z dorosłymi radnymi z rad miast/gmin oraz niskie zaangażowanie młodzieży. Tylko dalsza wytężona praca całego środowiska może przynieść poprawę w tych obszarach.

\section{Bibliografia}

Chodubski A. (2014), Młodziė̇ jako przedmiot i podmiot życia publicznego, w: Polityka młodzieżowa Unii Europejskiej, red. M. Boryń, B. Duraj, S. Mrozowska, Toruń.

Czubara T. (2008), Aktywność, tożsamość, plany i oczekiwania młodzieży województwa zachodniopomorskiego, Szczecin.

Dąbrowska-Resiak J., Jeżowski M. (red.) (2019), Polityka młodzieżowa w Polsce, FRSE.

Europejska Karta Uczestnictwa Młodych Ludzi w Życiu Lokalnym i Regionalnym, http://www.coe.int/ cplre, 30.05.2019.

Komisja Europejska, https://ec.europa.eu/, 30.05.2019.

Polska Rada Organizacji Młodzieżowych PROM, https://prom.info.pl/, 30.05.2019.

Raport „O Młodzieżowych Radach. Analiza stanu obecnego rad młodzieżowych w Polsce” (2018), Rada Dzieci i Młodzieży RP, Warszawa.

Raport „Młodzi o polityce młodzieżowej w regionie Morza Bałtyckiego. Dokumentacja projektu „Ku demokracji" (2009), praca zbiorowa, Szczecin.

Rodziewicz M. (2016), Proces ksztaltowania polityki młodzieżowej w Polsce na poziomie centralnym, „Zbliżenie Cywilizacyjne”, nr 1(1), s. 92-114.

Sińczuch M. (2009), Polityka młodzieżowa jako odrębny obszar działania Unii Europejskiej, w: Polityka młodzieżowa, red. G. Zielińska, „Studia BAS”, nr 2(18).

Skocz M., Postawa K., Prokopowicz M. (2009), Czym jest polityka młodzieżowa?, raport z projektu Dolnośląskiego Urzędu Marszałkowskiego, Wrocław.

Sekretariat ds. Młodzieży Województwa Zachodniopomorskiego, młodzież.wzp.pl, 30.05.2019.

Strategia Państwa dla Młodzieży na lata 2003-2012, www.mlodziezowarada.pl/files/bank_wiedzy/05. doc, 30.05.2019.

Sprawozdanie z działalności Sekretariatu ds. Młodzieży Województwa Zachodniopomorskiego za rok 2017, http://mlodziez.rbip.wzp.pl/, 30.05.2019.

Sprawozdanie z działalności Sekretariatu ds. Młodzieży Województwa Zachodniopomorskiego za rok 2007, http://mlodziez.rbip.wzp.pl, 30.05.2019.

Wyniki konkursu Europejskiego Kongresu Młodzieżowych Rad, https://ec.europa.eu/poland/ news/190524_konkurs_pl?fbclid=IwAR29DTMZzHdwh3IMT182smG_1RNfpaiPbki7Itb4knEaTbbZ4MU_Bo3fQ, 30.05.2019.

${ }^{3}$ Ogólnopolskie badania Rady Dzieci i Młodzieży wskazują, że w Polsce na 408 rad, jedynie 37 z nich w 2017 roku miało własny budżet. 


\section{Rozmowy:}

Rozmowa z Kornelem Grabowskim - przewodniczącym Rady Młodzieży Województwa Zachodniopomorskiego.

Rozmowa z Janem Borowskim - radnym Rady Miasta Świnoujście.

Rozmowa z Elżbietą Frankowską - radną Rady Miejskiej w Złocieńcu.

\section{Youth Policy in Westpomeranian Region - local and regional aspects}

\section{Summary}

The article deals with youth policy in the Westpomeranian Region. The author focused in particular on the local and regional aspects of this policy.

Its aim is to diagnose the situation of youth policy in Westpomeranian Region at the regional and local level. The author asked the following research questions: does the system of youth policy work properly? What is the thematic scope of youth council activities? Do young people involved in youth policy know the mechanisms of its functioning in the Westpomeranian Region? Do the Secretariat for Youth of the Westpomeranian Region and the Youth Council of the Westpomeranian Region fulfill their function of running youth policy in Westpomeranian Region? To find answers to the above research questions, the following methods were used: analysis of existing data, survey and interview techniques.

The conducted analyzes showed the recognition and visibility of the activities of Secretariat for Youth and Youth Council of the Westpomerania in the region. The research indicated that Youth Council of Westpomerania has an increasing impact on youth policy and Westpomeranian Region. Through the analysis of data, the correct dynamics of formation of youth councils in the region was observed. Some problems of youth policy were also diagnosed, i.e. lack of budget, lack of cooperation with adults and low youth involvement. According to the author, these elements require further work of entities involved in youth policy.

Key words: youth policy, local policy, regional policy, social participation 